\title{
SOUND RECORDING DYNAMICS IN BANDURA ART OF UKRAINIAN DIASPORA IN THE XX - THE BEGINNING OF XXI CENTURIES
}

\section{Dutchak V. H.}

\section{INTRODUCTION}

Bandura art, as a separate kind of professional folk art of Ukrainians, from the twentieth century has received new vectors of development, determined not only by changes in immanent features of instruments, genre-style priorities, education conditions, forms of performance, but also the by the expanding of territorial boundaries caused by the spread of this kind outside of the Ukraine. The new socio-political and cultural conditions in Ukraine, the specificity of cultural formation in other countries of the world provided the dynamics of the bandura art development, which affected many levels: structural, logical, culturalartistic, communicative, etc.

What was important in the development of the diaspora bandura art the absence of political (e.g. censorship) harassment about the bandura, including its repertoire, which made it possible to preserve the unique epic genres - dumas, historical songs, spiritual songs, psalms, as well as heroicpatriotic liberation songs. The prominence of overseas bandura art has identified the priority of solo male performance, both traditional and the latest chapel-ensemble, driven by the need of gathering by Ukrainians, who live abroad. The artistic achievements of soloists and leading bands of bandura players helped to popularize the best samples of folk music and art of Ukrainian composers, presenting Ukrainian culture in the world.

In the contemporary art of the diaspora, with the assistance and activity of bandura masters, the traditions of the Kharkiv-Poltava method of playing were preserved and promisingly developed. The reconstructed and improved instruments made it possible to reproduce both the authentic kobzar repertoire and the contemporary bandura art of composers and performers. 
Due to the aforementioned factors, it was precisely outside the borders of Ukraine - in the diaspora - that the sound recording of the bandura's epic-song and instrumental concert repertoire was initiated, which significantly outstripped similar processes in mainland Ukraine. Bandura art of the diaspora actualized the cultural dialogue between Ukraine and foreign countries, significantly influenced their rapprochement, mutual search for new approaches in developing of this artistic kind, including the means of sound recording.

\section{Historical, cultural and social factors in the sound recording development in Ukrainian diaspora}

If a sheet music allows you to analyze composer's art (genre, formative and dramatic principles, melodic, rhythmic, harmonious features of pieces, principles of instrumentation or orchestration, etc.), then only the performance reflects the features of interpretation, style and manner of its carriers, the special atmosphere ("aura") of playing or singing. But as the composer's work remains preserved in the sheet texts, the performance is only preserved in the music-critical reviews and memories of direct listeners. This problem has disappeared with the advent of performance fixing with the help of sound recordings, their promotion through duplication. The pioneer of the Ukrainian phonorecording Yevgeniya Linyova considered this method "free from oral subjective influence, thus keeping the songs in their pure form and in all their immediate melodic beauty".

During the twentieth century, methods and forms of recording changed. These changes primarily concerned the technical improvement of recording techniques: mechanical, magnetic, optical and magnetic-optical, flash memory recording; recording samples: phonograph wax rollers > gramophone record players > reel magnetic tapes > cassette tapes for record players > optical CDs and MP3s > digital DVDs; recording quality: mono sound $>$ stereo sound $>$ digital recording and audio processing.

Improvement of audio recording technique also led to the development of playback and sound transmission mechanisms.

\footnotetext{
${ }^{1}$ Линева Е. Опыт записи фонографом украинских народных песен [подгот. к изд., вступ. ст. и комм. Е. И. Мурзиной]. К.: Муз. Україна, 1991. 77 с.
} 
Accordingly, the ability to store not only audio, but also emotional and aesthetic information was constantly expanding. The sound recording fixed the interpretation as an achievement of performers (instrumentalists, singers, conductors) not only for contemporaries but also for future generations. This improvement allowed to compare the level of artistic creativity of different time periods. Nowadays, sound recordings can in fact be considered as the only authentic (as compared to listening or criticism) source of historical and performance research, a music bibliography. After all, the written text now means not only sheet texts but also sound recordings. Flashlight, vinyl records, reel tape became the basis of sound documentation. However, these are not adequate phenomena. Written and audio record a single version of the work, but the sound contains elements, albeit a single, but live performance, interpretation of the elements of phrasing, dynamics, agogics, which are denoted schematically in the text.

However, notation remains an important ingredient in scientific research. Sound recording cannot be captured by sight, analytically compared - "vision is generally more objective, more stable, more accurate than hearing" . Therefore, the most reliable for performing analysis is the symbiosis of notated and sound-fixed musical text.

Sound recordings are considered not only as a result of the processes of musical performance, but also an additional component of its communicative function. After all, in foreign countries, when Ukrainian artists did not have sufficient opportunity (financial and temporal) for professional concert or touring activity, the sound recording sometimes became the only way to communicate with the listener, to some extent even the dominant form of Ukrainian musical life in a non-national environment, with a favorable perception of national musical culture.

The field of sound recordings can be considered as a separate significant page of Ukrainian diaspora cultural achievements. A wellknown researcher of this area, Stepan Maksymyuk notes: "Recording activity is the most significant cultural heritage of the Ukrainian community in the diaspora, which is growing not only quantitatively but also qualitatively. The records put a certain mark on our emigration, these

\footnotetext{
${ }^{2}$ Выготский Л. Психология искусства. М.: Искусство, 1965. С. 63-68.
} 
are traces of our growth, our contribution to the all-Ukrainian spiritual treasury" ". Catalogs of recordings, including bandura, are in fact a separate branch of source science - discography ${ }^{4}$, a kind of musical and performance bibliography, sounded by literature. Roman Savycky noted that "a successful sound recording is a happy marriage of art with technology", Indeed, for example, bandura players' recordings reflect the evolution not only of technical thought (from waxes, discs to the reel tape of various format, digital recording), but also of artistic achievements (performance, playing technique, changes in instrumentation, repertoire genre priorities) and aesthetic requests of the audience. As Oleksandr Koshytz noted, "the recording of our song acquires cultural significance and weight", reflects "the necessity to combine business interests with the interests of music and culture, to give records not only interesting and valuable from the cultural and the music side, but to satisfy the average buyer"6.

The relevance of the bandura players' performance research highlights the recordings as a separate direction in addition to the notation samples of the repertoire, as well as the need for generalization of "audio publications", creation of a sound archive or corresponding thematic catalogs. "Once upon a time, as a cultural nation, such catalogs will have to be published, because it will show our national maturity and ability to honor the achievements of past generations"7, - S. Maksymyuk emphasized. However, there is also a need to analyze the purely technical and acoustic problems of sound recording, in particular, reverb ("echo, to

${ }^{3}$ Максимюк С. Голкою по платівках. 3 історії українського звукозапису та дискографії. Львів; Вашингтон: В-во Укр. Католиц. ун-ту, 2003. С. 67.

${ }^{4}$ Discography (fr. disque - disk, plate and gr. grapho - write) - content description and record arrangement, catalogue, lists, periodical sections with annotated lists of records, recordings of the notable artists, sheet music bibliography, contents display, abstracts, books, etc.

${ }^{5}$ Савицький Р. Прелюдія. С. Максимюк. 3 історії українського звукозапису та дискографії. Львів; Вашингтон: В-во Укр. Католиц. ун-ту, 2003. С. 10.

6 Максимюк С. Справа запису останніх грамофонних платівок О. Кошиця. 3 історії украӥнського звукозапису та дискографії. Львів; Вашингтон: В-во Укр. Католиц. ун-ту, 2003. С. 57.

7 Максимюк С. Голкою по платівках. 3 iсторії українського звукозапису та дискографії. Львів; Вашингтон: В-во Укр. Католиц. ун-ту, 2003. С. 71. 
revive the sound and to add some grandiosity" ${ }^{\prime 8}$ ) and the number and method of microphone placement, to ensure optimal balance of singing and instrumental play.

The bandura art of the Ukrainian diaspora aimed not only to promote Ukrainian music, but also to maintain a close connection with the traditions of mainland Ukraine. Of course, the processes of bandura art "academization" that took place in Ukraine (establishing a system of training of bandura players, development of new repertoire genres, activation of both solo and collective performance forms), could not be observed in the diaspora environment. The dynamics of the diaspora bandura players' performance on the example of sound recordings can be traced from the analysis point of view at several levels: historical stages; genre - instrumental or vocal-instrumental (composing and combined); forms - solo (male, female) and ensemble (homogeneous, mixed); instruments - diatonic, chromatic; instrumental timbre (homogeneous bandura or in timbre combination - violin, lyre, soprano, flute, percussion, chamber or symphony orchestra, synthesized timbre of electronic instruments, etc.); repertoire - authentic folklore and its reconstruction (dumas, historical songs), spiritual genres (cantos, psalms), academic folkinstrumental music (original, including processing of folk songs), works of pop music, World Music, New Age; style of performance - authentic traditional, professional academic, folk-amateur, avant-garde.

There are two historical periods in the development of bandura player recordings: ethnographic-research and commercial (by destination). If the first one was intended to preserve authentic ethnic specimens of the Ukrainian epos, the latter includes "records made for the purpose of duplication and sale, that is, commercial ones for sale", though not devoid of scientific and artistic value as stated (by I. Klymenko). Note that the discography of Ukraine and the Diaspora contains significant information (material selection criterion, certification of authentic performers, geographical territories, genres), reflecting both the form of performance, the thematic orientation, and the temporal social and artistic-aesthetic

8 Максимюк С. Справа запису останніх грамофонних платівок О. Кошиця. 3 історії українського звукозапису та дискографії. Львів; Вашингтон: В-во Укр. Католиц. ун-ту, 2003.С. 61. 
section of listeners' requests (for which "sample of commercially "nostalgic" repertoire" was made $)^{9}$.

So historically, in folklore music, as well as in kobzar art, that the first audio recordings were dumas, fixed on wax rollers by famous researchers Yevgenya Linyova, Filaret Kolessa, Lesya Ukrainka, Klyment Kvitka, Opanas Slastion from kobzars and lyricists of Kharkiv region (Hnat Honcharenko, Stepan Pasyuga, Ivan Kucherenko, Petro Drevchenko), Poltava region (Mykhaylo Kravchenko, Mykola Dubyna, Anton Skoba, Yavdokha Pylypenko).

Ye. Linyova claimed that "the phonograph helped ... to understand correctly the peculiarities of different people's performance and the structure of Ukrainian songs" $"$. The most important theoretical generalizations of the results of his own expedition and the study of recordings were presented by F. Kolessa at the 3rd International Congress of the Musical Society in Vienna (1909) and later in two published volumes of "Melodies of the Ukrainian Folk Dumas" $(1910,1913)$ which became not only the fixation of the contemporary performance, but also the possibility of analyzing vocal and instrumental individual features of singing and playing kobzars. Discussions of well-known instrumentalists and ethnographers-folklorists (in particular, E. Hornbostel and L. Cuba) became resonant. "The genius of F. Kolessa was a subtle sense of music and the ability to decipher fragments of kobza recitals"11. Phonographic recording (and later sheet music) reflected the level of the performers' playing technique, the structure and the range of their instruments, the fine balance of the vocal part and the accompaniment, the special emotional fullness of the works of the kobzars: "Only a stone heart can not feel when a kobzar blind man ... pours out of his soul these mournful sounds, complaining about lawlessness in the world ... The main motive in their

9 Клименко I. Дискографія української автентичної етномузики: проблеми першопрохідця. Вісник Львівського ун-ту. Серія Філологія. Львів, 2010. В. 43. С. 280.

10 Линева Е. Опыт записи фонографом украинских народных песен [подгот. к изд., вступ. ст. и комм. Е. И. Мурзиной]. К.: Муз. Україна, 1991. 77 с.

${ }^{11}$ Максимюк С. Звукозаписи українських дум. 3 історії украӥнського звукозапису mа дискографії. Львів; Вашингтон: В-во Укр. Католиц. ун-ту, 2003. С. 79. 
songs is the longing for truth and the pity that injustice prevails in the world" $" 12$.

During the interwar period, there were not so many bandura recordings. There was a way bandura transition as an instrument in the academic sphere, and the male solo authentic tradition of kobzar art was gradually dying, giving way to collective forms (chapels of bandura players dominated by female warehouses). The Holodomor and the repression of the 1930s completed the ideological steps of official structures: "H. Khotkevych's attempts to create stage ensembles of kobzars were used by the Soviet authorities to neutralize ... kobzars, who were driven into collective farm chapels... From the Kiev and Poltava chapels, in 1935, they created the State Chapel of Bandura Players, [which] began to record on record labels to demonstrate the "flourishing" of the Ukrainian people's culture in a united Soviet state" ${ }^{13}$. As S. Maksymyuk emphasizes in his article "Recordings of Ukrainian Dumas" (1969): "It is highly doubtful that Moscow's chauvinistic politics against Ukraine could allow at that time any development of Ukrainian kobzar art and its recording on gramophone records for mass use" ${ }^{\text {.14 }}$.

Instead, the situation in diaspora was somewhat different. The discography researcher of Ukrainian folklore I. Klymenko characterizes this period as follows: "Some authentic kobza publications on record labels were interrupted with the establishment of Soviet power, and in the metropolitan tradition the "artistic" stage went by force into "collective farm art". At this time, the Ukrainian diaspora in America gave an unexpected surge in authentic (albeit somewhat specific) publications by art singers and musicians, as well as professional musicians, only recently detached from the indigenous tradition. This rapid upsurge in ethnic production happened due to a happy coincidence: the traditionally-minded Slavic immigrant society has met with a world of technical innovations and a free, demand-driven free market. Demand for such a society was fueled

12 Линева Е. Опыт записи фонографом украинских народных песен [подгот. к изд., вступ. ст. и комм. Е. И. Мурзиной]. К.: Муз. Україна, 1991. 77 с.

13 Зьола М. Кобзарське мистецтво в грамзапису. Вітчизна. 2005. № 7/8. C. $143-149$.

${ }^{14}$ Максимюк С. Звукозаписи українських дум. 3 історії украйнського звукозапису ma дискографії. Львів; Вашингтон: В-во Укр. Католиц. ун-ту, 2003. С. 79-80. 
by ethnic recordings: they were produced alongside "artistic" ones, but were more attractive to a large number of buyers. But this take-off was, unfortunately, only one or two generations long. It disappeared by mid1935 because of the economic crisis of the 1930s and the depression associated with it, later - the World War, as well as the fact that subsequent emigrants had lost touch with the traditions of their native land and did not need corresponding music"15.

The 40s were a turning point in world history, leading not only to the redistribution of the map of Europe, but also to numerous waves of emigration. It was the third wave of emigration in the late 1940s that became not only the most powerful in terms of quantity, but also in terms of qualitative social status - the predominance of intellectuals. This contributed to the emergence of bandura tribes, the formation of chamber and large groups - male, female, mixed, children's, learning processes, the publication of sheets and methodological materials, the activation of concert performance, and, accordingly, the recording.

The postwar period of the twentieth century. marked by much higher activity in the recording industry (especially in the North American continent - Canada and the US). It was during this time that most audio recordings were made, both quantitatively and qualitatively. A wide range of vocal-instrumental and instrumental works, solo and various ensemble forms, traditional kobza genres and author compositions were represented. As stated by S. Maksymyuk: "In fact, there are very few Ukrainian bandura players and kobzars in the free world compared to those in Ukraine, but the record achievements of bandura emigrants are far higher than the Ukrainian Soviet ones"16. This was due to the absence of censorship restrictions, the need to preserve traditional culture as a means of national identification, active artistic search for performers, and the openness of bandurists to creative innovation.

This situation continued until the 1990s - the period of Ukraine's independence. The performers of the fourth wave of emigration (late 80's -

15 Клименко I. Дискографія української автентичної етномузики: проблеми першопрохідця. Вісник Львівського ун-ту. Серія Філологія. Львів, 2010. В. 43. С. 281.

${ }^{16}$ Максимюк С. Звукозаписи українських дум. 3 історії українського звукозапису та дискографії. Львів; Вашингтон: В-во Укр. Католиц. ун-ту, 2003. С. 81. 
early 90's and till today) represent mainly the Lviv and Kiev academic schools of bandura performance, and accordingly formed traditions.

Democratic processes have contributed to the gradual intensification of the sound recording processes of bandura players in Ukraine, the emergence of bandura players collaboration in the world through concerts, festivals and forums.

\section{Genres, forms and style of audio-art among the Ukrainian diaspora bandura players}

Among the soloists from abroad, who were the first to record the bandura repertoire in the 1920s and 1930s. in France and Poland, Vasyl Yemetz and Mykhaylo Teliga became known performers, representatives of the Kharkov playing school. They include "artistic" recordings of instrumental plays (mostly variational and end-to-end forms), accompaniment of folk songs, epic and lyric-epic works. Their activity attests to the situation stated by S. Maksymyuk: "First, there were only units that had mastered the kobza arts... Secondly, the energy and intellectual power of emigration burned at that time, mainly in the direction of its socio-political obligations and needs, first of all, for the internal organization and for the external world to be aware of the true aspirations of the Ukrainian people. Cultural activities and acquisitions, especially such as gramophone records, were only a useful phenomenon, largely the result of the efforts of single artists or groups"17.

Vasyl Yemetz (1890-1982) was an active performer in France during 1929-1939, not only as a soloist, but also as an accompanist for singer Sophia Verbycka in performing her Ukrainian and Catalan songs and romances. In December 1929, the "Tryzub" magazine (Paris) reported about the sound recordings of Ukrainian artists at the French gramophone firm Pate, and as early as 1930 we read references and reviews to a doublesided disc: "Wonderful Singing by Mrs. S. Verbycka and Mr. V. Yemetz Artistic Play Sound Together Magnificent..."18.

There are also examples of bandura sound recordings belonging to Mykhaylo Teliga (1900-1942), who after the Czechoslovak period (1923-

${ }^{17}$ Максимюк С. Звукозаписи українських дум. 3 історї украӥнського звукозапису та дискографії. Львів; Вашингтон: В-во Укр. Католиц. ун-ту, 2003. С. 81.

${ }^{18}$ Фірма Пате у Парижі. Тризуб. 1930. 13 квітня. С. 21. 
1929) continued his concert activity in Poland (Warsaw, Krakow) until 1941. His 3 records were issued by a Polish firm "Syrena electro" in Warsaw in 1934, contained 7 works ("Zaporozhye March", "Hey, the village is visible", "Oh, the summer eagle", "Oh, don't go, Gryts", "The Challenge" ("What a Moonely Night"), "Tarasova Night", "Oh on the mountain the fire burns". Obviously, one can find a correlation between the prints (in the collection Our Song, Prague, 1926) and M. Teliga's audioworks, which testifies the placement in the collection of compositions that have already been tested on stage and by recording practice.

Bandura soloists, who recorded their audio recordings in the 1950s and 1960s in the United States, Great Britain, France, Germany Vasyl Yemetz, Zinoviy Shtokalko, Hryhory Kytasty, Volodymyr Lutsiv, Pavlo Konoplenko-Zaporozhets, Petro Honcharenko, Bohdan Sharko, Borys Tsybulsky, Roman Levycky and others.

The recorded live performance of V. Yemetz in the 50-60's included works from the repertoire of Hnat Khotkevych, kobzar Ivan Kucherenko, in particular, 7 dumas. In two of them he used tunes composed by H. Khotkevych, the others - taken from the traditional kobzar repertoire. V. Yemetz recorded in the 1950s his own instrumental compositions for record labels: "In the Mountains of Ukraine", "In the Steppes of Ukraine" and "Snow", which used melodic elements of folk songs, including historical ones.

Also important are two records by Borys Tsybulsky (1911-1963), a bandura player-tenor from post-war France. They feature folk songs of the lyrical nature "Tell me why I fell in love with you", "Oh, came that black cloud" and two moving songs-marches.

Among the rich musical heritage of this period is the numerous audio collection of bandurist from the USA Zinoviy Shtokalko (1920-1968), which contains vocal and instrumental recordings. During the life of the performer, only one of his records was issued (with the duma "About Marusia Boguslavka"). In general, the artist's recordings as a lifetime property belonged to Mr. Myron Surmach, the owner of the "Surma" shop (New York), on whose professional studio he recorded in 1952. The audioheritage of Shtokalko, with the help of S. Maksymyuk, was released on a 
long-running double-disc album ("Oh, My Dumas") ${ }^{19}$. Currently, part of the material is stored in the private archive of S. Maksymyuk and another part - in the Institute of Ukrainian Studies at the University of Alberta (Canada). Most of the works in recent years have been digitized, which made it possible to study his work by his followers, including A. Hornjatkevyč (Edmonton, Canada), M. Evgeneva (Ternopil, Ukraine) and the author of the study ${ }^{20}$.

Among the variety of recorded genres in Shtokalko's repertoire, vocal and instrumental pieces prevail: dumas, cantos, historical songs, songs of social groups - cossack, haydamaky, chumak, burlak, as well as dance, jocular and satirical. It is possible to distinguish into a separate group the works that are perhaps less popular in the kobzar repertoire, but in general enough common genres of songs: lyrical, lullabies, shameful ("erotic"), as well as with literary origin.

Among the vocal-instrumental works of Shtokalko's repertoire there are authorial songs - "Kozak Mamai", "Danilyshyn and Bilas", "Oh, a violent wind", "Oh, look, Uncle", "In Kiev at the bazaar" for folk texts for which he created a melody that was close in character to the historical songs.

The mastery of epic specimens pushed Shtokalko to the stylized reproduction of the ancient epic genre "bylyna" from the Kyivan Rus. He translated the text into Ukrainian from the old slavic language and, through experimentation, created a music soundtrack, imitating the sound of the "gusli" - a bandura-related ancient instrument. He composed quite a few of these bylynas - "About Dobrynia", "About the glorious man Illya Murometz and Soloviy the Sufferer", "About the glorious men Sviatogor and Illya Murometz".

Among the recordings of Shtokalko there are auto-duets made by recording overlay. Considering that most of Shtokalko's audio recordings were made in the 50's and 60's, these samples became a bold experiment in bandura art not only abroad but also in Ukraine. Autoduits include "Oj

19 Максимюк С. Докладніше про звукозаписи Зіновія Штокалка. 3 icmopii українського звукозапису та дискографіі. Львів; Вашингтон: В-во Укр. Католиц. ун-ту, 2003. С. 286.

20 Дутчак В. Музична спадщина Зіновія Штокалка. Наукові записки. Серія «Мистечтввознавство». Тернопіль; К., 2006. № 1(16). С. 29-37. 
hirka kalyna", "Oj na hori sukhyi dub", "Stoyit yavir nad vodoju”, "In the year of 1791" and others.

A separate group is represented by the bandurist's original instrumental works (two "Atonal Sketches", "Oriental Sketch" and two "Dream" fantasy sketches) - as experimental attempts to use the so-called "artificial" frets.

Individual interpretations of the traditional kobza repertoire are presented in the sound recordings of Hryhory Kytasty, Volodymyr Lutsiv, and others.

Hryhory Kytasty (1907-1984) - conductor, composer, long-time leader of the T. Shevchenko Ukrainian Bandurist Chorus (Detroit, USA), but he is no less known as a fine soloist-performer, interpreter of the traditional kobza repertoire, his own works. H. Kytasty recorded solo works - cossack, chumak, humorous and satirical scenes, dumas and historical songs ("Bandura renditions of ukrainian melodies including his own compositions") in the 1960s at RCA Custom Records. In 2006, the artist's solo audio recordings were reissued on two discs. Among the vocal and instrumental works in the recordings of Kytasty, the duma "Slave crying", historical songs, as well as humorous theatrical songs, for example, "About Yavtukh" are particularly striking. Among his works, the most popular were the instrumental composition "The Steppe Gomin" and the song by O. Pidsukha "How Long".

Bandura player and singer Volodymyr Lutsiv (1929) from the UK presented in his own repertoire a broad genre palette that can be considered typical for a professional concert performer (duma, folk song, romancesolos, instrumental compositions). The breadth of Lutsiv's repertoire is evidenced by the significant discography of the singer, which allows to determine the perfection of his performing skills during his creative career, cooperation with the leading musicians of his time - Byzantine Choir (Netherlands) led by M. Antonovych, Maiden Bandura Chapel (USA) led by K. Tsependa and others.

In 2009, the artist's anniversary CD set was released - a three-disc collection ("series") with records of his best works. It was based on the records of different years, published on vinyls and today translated into 
digital version (55 works) ${ }^{21}$. The rewritten disc of V. Lutsiv "Ukrainian Folk Songs and Dumas" includes samples of the ancient epic repertoire: "To the death of the Cossack bandura player", "Storm on the Black Sea" (ancient duma from kobzar H. Nazarenko). In the works of V. Lutsiv, Shevchenko works are represented by "A Rising Cloud Due to an Estuary" (music by V. Yemetz), "Bandurist, Gray Eagle" (folk music), "My dumas" (folk music), the duma "Slave" (T. Shevchenko, music by A. Golub). The bandurist performed the mentioned works on a Kharkiv-type instrument with an individual tone-switching system (by English master V. Glyad).

In V. Lutsiv's recordings there is a bold experiment of the time - the combination of bandura with other instruments: with a string chamber orchestra and with piano in instrumental and vocal-instrumental compositions ("Gavot" by M. Lysenko, song "Pond fell asleep", romance "Babak" by L. Beethoven and A. Duvernois' "Etude for Bandura and Piano". Musician Osyp Zalessky noted: "Your combination of bandura with bow instruments is very accurate and original; the bandura sounds like a harp ${ }^{22,}$.

Among the soloists from Ukrainian diaspora, one should be mentioned Pavlo Konoplenko-Zaporozhetz (1890-1974), who by his art asserted the right to independent existence of a kobza as "a separate instrument other than the bandura, with a more ancient predecessor origin"23. His "Kobza" disc (1961) contains various genres - instrumental samples and vocalinstrumental works - dumas and historical songs, humorous songs, individual instrumental arrangements. It should be noted that it includes "The duma about Baida" (by Khotkevych), the duma "Our Ukraine", the instrumental "Wind, come to Ukraine", "There is a high mountain" and others, famous folk songs-romances of literary origin (M. Hajvoronsky, R. Kupchynsky).

In the 70's, bandurist from Germany Bohdan Sharko (1920-2013) also made a number of audio recordings, in particular, his short-playing

${ }^{21}$ Collection was released in Kyiv by "Nash format" (creator and editor Orest Tsymbala and art association "Revia", Lviv): "With Ukraine in Heart", "Ukrainian songs and Dumas", "International songs".

22 Лист О. Залеського до В. Луціва. Музей історї Надвірнянщчини. Фонд В. Луцุіва. Листування В. Луціва з організаціями, приватними людьми тощо. Папки № 1-2.

${ }^{23}$ Конопленко-Запорожець П. Кобза і бандура. Вінніпег, 1963. 167 с. 
"Bandura Songs". It included works such as "Rising Cloud from the Estuary", "Thoughts on Morozenko", "Wind, come to Ukraine", "Black colour".

Volodymyr Mota (1927) from Montreal (Canada) is a bandura singer (bass), author of bandura arrangements. The bandurist uses a Kiev-type instrument, without a key-switching system, inlaid with a picture of T. Shevchenko. The performance of the bandura singer is recorded on two CDs: "Bandurist" (2006) and "T. Shevchenko's Works in Songs" (2011), dedicated to the 150th anniversary of T. Shevchenko's death.

Art of Honored Artist of Ukraine Victor Mishalow (1960), Australiaborn Ukrainian, now living in Canada, a brilliant virtuoso who has mastered different types of bandura and ways to play them (diatonic and chromatic, both Kyiv and Kharkiv type), covers different genre repertoire. Among the diaspora bandura soloists, he owns numerous audio albums (LPs, cassettes, compact discs), which include mostly instrumental works for the chromatic bandura - compositions by contemporary Ukrainian authors, his own folk songs arrangements, carols, and experimental samples of bandura combined with synthesyzed computer timbre ("The Magical Bandura", 1997; "The Christmas Enchanted Bandura", 1998) ${ }^{24}$. V. Mishalow also belongs to the primacy in the revival of bandura composer H. Khotkevych, the reproduction of traditional kobza music of the Kharkiv school - dumas, historical songs, instrumental dances.

Honored Artist of Ukraine, Laureate and Gold Medal Winner of the World Championship of Performing Arts (Hollywood, 2002) Olha Herasymenko-Oliynyk (1958) issued two instrumental disks in 1999 in the USA: "Concert Bandura" and "Three Concerts by Y. Oliynyk for Bandura and Symphony Orchestra" which presents the academic concert repertoire of modern bandurists - works of great form (concerts by Yuriy Oliynyk, Karl Dittesdorf, Dmytro Bortniansky), virtuoso and lyric plays by Myroslav Skoryk, Oksana Herasymenko, etc.

Alina Ilchuk, a graduate of the Lviv Academy of Music, now living in the United States and also actively performing as a soloist, released an

${ }^{24}$ Дутчак В. Пошук синтезу традицій і новацій української бандури в творчій діяльності Віктора Мішалова. Мистеитвознавчі записки. Київ, 2007. В. 11. С. 170-177. 
audio CD, "Bless My Soul, Lord ..." (2000), which included works of spiritual and lyric-patriotic themes.

In the last decades of the twentieth century, bandurists of North America and Australia recorded most of their solo performance: Julian Kytasty, Roman Botsyurkiv, Brian Cherwick, Petro Deryazhny, Yuri Fedynsky, Ruta Yawney, Yuriy Petliura and others. Most performers prefer diatonic instruments, more often Kharkiv, rarely Kyiv, they try out experimental instruments of modern masters V. Vetzal, K. Bloom, musical styles - World Music (J. Kytasty, B. Cherwick0), New Age (R. Yawney).

Bandurist Julian Kytasty of the United States (1958), in collaboration with the famous singer of Ukrainian origin Alexis Kohan, recorded 3 CDs of the "Paris to Kyiv" project (1996). In them, bandura appears as a timbre indicator of Ukrainian art, even in combination with exotic percussion. In 1997 Julian Kytasty in New York released a solo disc with compositions by Hrygory Kytasty (instrumental and vocal-instrumental), the following 1998 he participated in the Experimental Bandura Trio in New York (Yuriy Fedynsky, Mykhailo Andrec, Julian Kytasty), with which triggers an album of improvisational music. 2002 his solo album of traditional kobza music "Black Sea Winds" is released, which contains the dumas "Marusia Boguslavka", "About Sister and Brother", "Crying Slaves", "About Widow and Three Sons", "Fedir Bezrodny", Ukrainian dances, historical and humorous songs. J. Kytasty's disc "Songs of Truth Melodies and Songs of the Kobzar Tradition" (2014) presents cantos and psalms from the recordings of M. Lysenko, P. Demucky, satirical songs and dances on a diatonic bandura. The improvisational nature of the kobza repertoire is reflected in another audio CD by J. Kytasty "Nights in Bandurastan" (2015), intsrumental compositions of which are based on tradional kobzar modes, create specific sound space effect. Quite unexpected is the following disc by J. Kytasty "Perturbed Fields" (2016), made in a collaboration with famous Ukrainian composer Alla Zahaykevych. The disc's three audio tracks (titled "Fields I, II, III") are a combination of bandura timbre and computer music in a creative collaborative improvisation. Kharkiv bandura was used for the recording, and for one of the tracks a tool was discovered, which reveals innovative experimental approach of the authors to composing. 
Sisters-bandura players Natalia and Katerina Gudziy (Japan) use bandura to accompany vocal and instrumental works in Japanese ${ }^{25}$. Songs and arrangements by N. Gudziy for radio and television programs, films, concert performances, sound recordings ("Heart", 2002; "Happy Christmas", 2004, "Flowering flower in the soul", 2006, "Natalia", 2009, "Healing", 2009) are very popular, testify to the possibility of Ukrainian bandura successfull integration into another national culture.

In Ruta Yawney's (Canada) audio CD "Songs to the Moon" (2001), featuring lullabies and nocturnes, the bandura's timbre serves as an acoustic component of calming character, and is an instrumental sound element of the album's music-therapeutic content.

A specific page is made up of ensemble records, which are activated in parallel to the expansion of the network of functioning of Ukrainian bandura tribes in the world - most of them belong to the second half of the $\mathrm{XX}$ - the beginning of the XXI century.

The most strikingly represented by the sound recordings is the work of the Taras Shevchenko Ukrainian Bandurist Chorus (Detroit, USA), who in all periods of activity invariably recorded their performing achievements on records, cassettes, disks, having worked over 600 works of bandura and choral repertoire. For the significant contribution to the development of national culture, the Taras Shevchenko Ukrainian Bandurist Chorus (Detroit, USA) was awarded the National Taras Shevchenko Prize of Ukraine (1992), and her longtime leader, Hryhory Kytasty, was posthumously awarded the Honorary Mention of Hero of Ukraine (2008) ${ }^{26}$.

Some recordings were also made by the Diaspora ensemble "Burlaca" ensemble (Italy - Great Britain), the S. Ganushevsky ensemble, the R. Levycky quartet, the Bandurist maiden's chapel (the head of P. Potapenko), and the "Gomin steppes" ensemble of the Kobzar Art School (J. Kytasty), Experimental Bandura Trio (USA), Hnat Khotkevych Bandurist Ensemble (Australia), Kobzar Brotherhood Quartet (L. Mazur, UK), "Bandura" ensemble (O. Popovych, Poland), "Bandura" ensemble (Y. Dubicky, France - Germany) and others.

${ }^{25}$ Гудзій Наталія. Офіційна сторінка. URL: http://www.office-zirka.com/; Гудзій Катерина. Офіційна сторінка. URL: http://www.kateryna-music.jp.

${ }^{26}$ Ukrainian Bandurist Chorus. URL: http://www.bandura.org. 
In the 60's bandurists recorded rifle and rebel songs (mixed quartet by Roman Levycky and Stepan Ganushevsky's bandurist ensemble from the USA).

Bandura also acts as a companion instrument for homogeneous groups, for example, with the Canadian female trio "Swans" recorded by bandurist P. Kosyk (1975).

In the audio art of diaspora bandurists (soloists and collectives), Christmas carols and shchedrivkas are widely represented - genres that have been banned for a long time in Soviet Ukraine. These are audio recordings of the SUM (Ukrainian Youth Association) Bandura Chapel ("Ukrainian Christmas carols", 1968), Taras Shevchenko Bandura Chapel (“Christmas Songs" 1983, "Christmas Night”, 1999), Kobzar Brotherhood Quartet (1987), Victor Mishalow "Enchanted Christmas Bandura" (an instrumental version in the style of ethno disco, 1998), duet of sisters Olha and Oksana Herasymenko ("For Christmas", 1999), children's chapel "Golden Strings" ("Kolyada", 2008) and others ${ }^{27}$.

Canadian Bandura Chapel released two CDs (2004, 2009), which included popular works by the ensemble repertoire, often performed by bandura collectives of the diaspora and Ukraine, including V. Yemetz, H. Kytasty, M. Hvozd, H Vereta, A. Bobyr . The disc "Play, kobzar" covers the original works and arrangements by V. Mishalow, A. Hnatyshyn, H. Kytasty, D. Pika and others. A third CD, called "The Word of Taras," is coming soon ${ }^{28}$.

In recent years, new bandura ensembles have been created abroad the "Zaywir-Trio" (UK), J. Kytasty's "Bandura Downtown" (USA), and the "Bandura Outside Men's Quartet" (Canada), who are preparing their own records for the publication.

\section{CONCLUSIONS}

Thus, during the twentieth century. the gradual improvement of the recording technique contributed to the longevity of the bandura

27 Дутчак В. Бандурне мистецтво українського зарубіжжя [монографія]. ІваноФранківськ: Фоліант, 2013. С. 290-315.

28 Дутчак В. Аудіотворчість бандуристів української діаспори. LAUDATIO: Ювілейна збірка наукових статей на пошану професора Юрія Ясіновського. Львів: Видавець Т. Тетюк, 2014. С. 235-245. 
performance art (stylistics, dominant genres, features of the repertoire at different historical stages). Also, sound recording was used as a ground for reproduction (transcription) of works that were not recorded in the sheet music, for comparative characterization of the manner or style of play of the musicians.

Analysis of Ukrainian diaspora bandura players sound recordings of the XX - the beginning of the XXI century allows to define them as a kind of distribution mirror for forms and genres of performance: male, female, mixed; solo - vocal-instrumental or instrumental; ensemble - chamber (duets, trio, quartets) and large forms (chapels); accompanying (combined).

Regarding the priority genres of the repertoire, an important page of the bandurists' sound recordings is occupied by traditional epic works: dumas (recordings by M. Teliga, V. Yemetz, Z. Shtokalko, H. Kytasty, V. Lutsiv, B. Sharko, V. Mishalow, J. Kytasty, Y. Fedynsky and others), historical songs (represented not only by solo, but also by ensemble performance - the Taras Shevchenko Ukrainian Bandurist Chorus, Canadian bandura Chapel, R. Levycky Quartet, S. Ganushevsky's Ensemble, "Bandura", "Kobzar brotherhood", "Selo" ensembles and others), "bylyny" (Z. Shtokalko).

In the repertoire of Bandura players, "Shevchenkiana" constantly became an integral (along with epic, folk song) and topical (ideological, socio-political, patriotic) component. Shevchenko's word embodied national self-identification, understanding and awareness of one's ethnicity. "Shevchenkiana" is recorded in the performance models of bandurists abroad relatively broadly by genre - in solo (M. Teliga, V. Lutsiv, B. Sharko, V. Mota) and collective (the Taras Shevchenko Ukrainian Bandurist Chorus, Canadian Bandura Chapel, numerous ensembles).

Significant achievements were bandura recordings of spiritual liturgical works of A. Hnatyshyn, D. Bortniansky, A. Vedel, M. Gaovoronsky, O. Koshytz, H. Kytasty, M. Lysenko, D. Sichynsky, K. Stetsenko, etc., as well as paraliturgical cantos and psalms.

The instrumental bandura repertoire is represented mainly by solo art of performers with high technical level (M. Teliga, V. Yemetz, H. Kytasty, V. Lutsiv, V. Mishalow, J. Kytasty, B. Cherwick, 
Y. Fedynsky, O. Herasymenko-Oliynyk, Y. Petliura, etc.), representing the chromatic and diatonic instruments of the Kyiv and Kharkiv schools of playing, as well as traditional popular dance plays, improvisations, and widespread academic genres - sonata, concerto, virtuoso plays, in including piano or symphonic accompaniment (chapel) orchestra. Bandura is also considered as a specific timbre in an ensemble with violin, string quartet, flute, lyre, cymbals, percussion and electronic instruments. The traditional sound of the bandura as an accompanying instrument to the solo voice in the audio recordings of bandura diaspora players is getting a new interpretation - as an instrument accompanying a vocal ensemble (homogeneous or mixed).

The study of the Ukrainian diaspora bandura player collective performance art discography during the studied historical period testified that the ensemble recordings were activated in parallel to the expansion of the Ukrainian bandura units network in the world, most of them being in the second half of the XX - beginning of XXI century. Among the forms of ensemble recordings, homogeneous vocal-instrumental groups (children, men, to a lesser extent women) are more dominant, less often mixed ones.

The gender specificity of bandura diaspora performance should also be noted, which is also fixed in the recordings. The tradition of solo and ensemble male performance remains a priority throughout the XXth century. Instead, women performance has been more representative of collectiveart in homogeneous and mixed groups since the 1960s ("Bandura Maiden Chapel" - USA, "Bandura" - Poland, etc.). Solo projects are presented by creativity of individual performers with a bright artistic personality (O. Herasymenko-Oliynyk, R. Yawney, O. Friz, A. Ilchuk, N. Gudziy, etc.).

The performance styles formation, which was manifested in the selection of the repertoire for recording, revealed their focus on both the internal signs of kobza playing and singing (national) and external (nonnational, non-Ukrainian artistic environment).

\section{SUMMARY}

The proposed study deals with the analysis of the Ukrainian diaspora bandura players recording dynamics during the $\mathrm{XX}$ - the beginning of the 
XXI century. The reflected dynamics of both general technologies of preservation and reproduction of performing achievements, as well as artistic achievements of Ukrainian units abroad in different periods of development, professional growth of their representatives, in particular quality of playing technique and singing, specifics of instruments, dominance of playing genres, repertoire priorities. In the conditions of emigration, the recording became a necessary form of collective performance fixation (including various compositions), the development of their repertoire, stimulated not only music-critical (reviews and reviews), but also advertised concert-performing activities.

\section{REFERENCES}

1. Дутчак В. Аудіотворчість бандуристів української діаспори. LAUDATIO: Ювілейна збірка наукових статей на пошану професора Юрія Ясіновського. Львів: Видавець Т. Тетюк, 2014. С. 235-245.

2. Дутчак В. Бандурне мистецтво українського зарубіжжя [монографія]. Івано-Франківськ: Фоліант, 2013. 488 с. +72 іл.

3. Дутчак В. Г. Виконавські моделі в аудіографії та відеографії бандуристів українського зарубіжжя. Вісник Прикарпатського університету. Мистецтвознавство. Вип. 26-27. Івано-Франківськ: ДВНЗ «Прикарпатський університет імені В. Стефаника», 2012-2013. С. $166-173$.

4. Дутчак В. Звукозаписи епічного репертуару бандуристами українського зарубіжжя. Вісник Прикарпатського університету. Мистецтвознавство. Вип. 21-22. Івано-Франківськ: Прикарпатський національний університет імені Василя Стефаника, 2011. С. 257-263.

5. Дутчак В. Форми, жанри і стилі виконавства в бандурному мистецтві українського зарубіжжя: звукове відтворення. Етнос $i$ культура. Івано-Франківськ: Вид-во Прикарпат. нац. ун-ту ім. В. Стефаника, 2011-2012. № 8-9. С. 140-146.

6. Карась Г. Музична культура української діаспори у світовому часопросторі XX століття [монографія]. Івано-Франківськ: Тіповіт, 2012. 1164 c.

7. Клименко I. Дискографія української автентичної етномузики: проблеми першопрохідця. Вісник Львівського ун-ту. Серія Філологія. В. 43. Львів, 2010. С. 272-293. 
8. Клименко I. Дискографія української етномузики (автентичне виконання). 1908-2010: Ілюстрований хронологічний реєстр 3 анотаціями і покажчиками. Київ, 2010. 360 с., іл.

9. Максимюк С. 3 історії українського звукозапису та дискографії. Львів-Вашингтон: Видавництво Українського Католицького ун-ту, 2003. $288 \mathrm{c}$.

10. Степан Максимюк. Бібліографія українських звукозаписів 1903-1995 / ред. Юрій Ясіновський. Львів, 2014. 116 с.

\section{Information about the author:}

Dutchak V. H.

Doctor of Art Criticism, Professor,

Head of the Music Ukrainistics

and Folk Instrumental Art Department,

Vasyl Stefanyk Precarpathian National University 57, Shevchenko str., Ivano-Frankivsk, Ukraine 